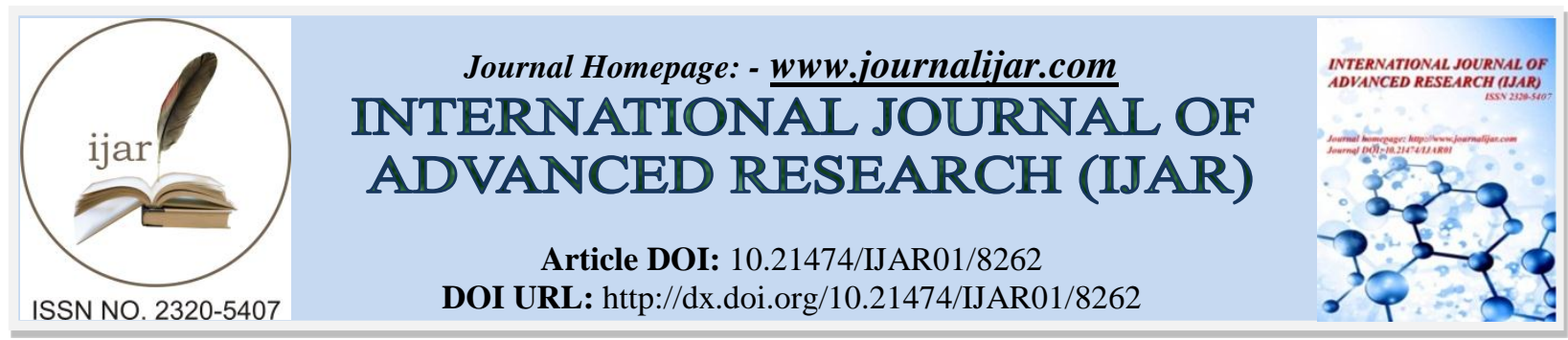

RESEARCH ARTICLE

\title{
SILICON STENT AS A FAILURE IN ENDONASAL ENDOSCOPIC DCR.
}

\author{
Shahnaz Sheikh ${ }^{1}$,Manzoor Ahmad Malik ${ }^{2}$, Anushree Bajaj ${ }^{3}$ And Balchandra Paike ${ }^{4}$. \\ 1. Senior resident dr ulhas patil medical college jalgaon . \\ 2. Consultant $\mathrm{jk}$ health services. \\ 3. Associate professor dr ulhas patil medical college jalgaon . \\ 4. H.O.D dr ulhas patil; medical college jalgaon .
}

\section{Manuscript Info}

\section{Manuscript History}

Received: 20 October 2018

Final Accepted: 22 November 2018

Published: December 2018

Keywords:

Endonasal endoscopic DCR, chronic

dacryocystitis, silicon test.

\begin{abstract}
Objective: 1 . To evaluate the effectiveness of using the silicon stent in endonasal endoscopic DCR 2. To compare the results of endonasal endoscopic DCR using silicon stent with endonasal endoscopic DCR without silicon

stent.

Material and methods: our study included 36 patients were divided into two groups. First group underwent endonasal endoscopic DCR using silicon stent and in the second group endonasal endoscopic DCR was done without using silicon stent.Postoperative follow up was carried out at the end of first,third,six,and 1oth week and the role of silicon stent was compared Results: we found that with the use of silicon stent results were not improving despite the risk of failure of the surgery was increased with stent due to the formation of granulation tissue in the lacrimal sac region.
\end{abstract}

Copy Right, IJAR, 2018,. All rights reserved.

\section{Introduction:-}

Dacryocystorhinostomy consists of a creating a lacrimal drainage pathway to the nasal cavity to restore permanent drainage of previously obstructed excreating system.In otherwords DCR is an operation that creates a lacrimal drainage pathway into the nasal cavity to faciloitate dtrainage of the previously obstructed excreatory system. DCR is indicated in nasolacrimal duct obstruction. The first intranasal DCR was described by Caldwell in 19831. In 1989, McDonough and Meiring 2 described endoscopic transnasal DCR.The causes of nasolacrimal duct obstruction are idiopathjic, iatrogenic, congenital,traumatic, lithiasis and infection.the nasolacrimal duct obstruction can be confirmed by sac syringing, Jones test and dacryocystorhinography.Some of the common advantages of endoscopic DCR include the avoidance of external scar, preservation of the pumping mechanism of the orbicularis muscle and avoidance of possible injury to the medial canthus,correction of associated intranasal pathologies like deviated nasal septum, rhinosinusitis and a decreased surgical duration with better intraoperative visualization3. The reported success rate of for endoscopic DCR varies from 50\% to 97\% ndepending on the technique, obstruction level and and the use of silicon stent4. The most common reasons for the failure of endoscopic DCR include adhesions, restenosis, and obstruction of common cannaliculous5.Insertion of a silicon stent is the most common procedure to prevent the rhinostomy closutre6.It has been claimed that the silicon intubation improves the surgical outcome of endonasal enoscopic DCR by delaying fibrous closure during the post operative healing period and consequently maintaining the patency of fistula7.However some studies have rep[orted that the use o0f silicon stent itself may

Corresponding Author:-Shahnaz Sheikh.

Address:-Senior resident dr ulhas patil medical college jalgaon. 
cause granulation tissue formation, predisposing the site to postoperative infections, adhesions, and punctual ulcerations, and causing surgical failure8.Allen and Berlinj 9reported a higher failure rate when using silicon tubing. Stenting of nasolacrimal duct system is aloso associated with complications including punctual fibrosis and tear of cannaliculi.

\section{Material and methods:-}

this study was carried out at dr ulhas patil medical college jalgaon Maharashtra. About 36 patients were included in the study. Patients who were selected for endonasal endoscopic DCR included middle aged with acquired primary chronic dacryocystitios with cannalicular and nasolacrimal sac or duct obstruction,mucoprulent material reflex,evidence of obstruction on probing and irrigatioin. For endonasal endoscopic DCR all the patients with acute and chronic dacryocystitius unresponsive to medical treatment were included in the study. Complete ophthalmologic examination was done. Probing and sac syringing was done to confirm the diagnosis.Complete ENT examination was done including preoperative nasal endoscopu. Radiological examination including X ray and CT scan nose and paranasal sinuses was done in each case. Cases were divided into two groups . Group A underwent endonasal endoscopic DCR and silicon stent was used.. Group B patients were subjected to endonasal DCR and no stent was used.Silicon stent was kept for 6 weeks postoperative in group A patients.

All the surgeries were done under local anesthesia. One ampule of fortwin injection(pentazocin30 mg) one ampule of injection phenrgon(promethazine $25 \mathrm{mg}$ ) were mixed and half of this mixture were given 30 minutes before surgery and remaining half was given just before the surgery.The patient was placed in a supine position and preprared as for endoscopic sinus surgery. Nasal cavity was packed with a ribbon gauze soaked in a solution of 30 $\mathrm{ml}$ of topicalxylocaine $4 \%$ with 3 ampules of injection adrenaline.local infiltration using 1:100000 adrenaline:lignocaine solution was given in the lateral wall of the nose. Zero degree and 30 degree rigig endoscopes were used for surgery. . Patient was kept in supine position with diseased eye of the patient were left uncovered.Anterior ethmoidal nerve block was given.Lateral wall of nose anterior and above the axilla of middle turbinate was infiltrated with $2 \%$ lignocaine and 1:100000 adrenaline solution. 0 degree , 4 mm endoscope were used for the procedure. C shaped incision was made using sickle knife infront of anterior attachment of middle turbinate.Posterior based mucoperiosteal flap was elevated using a Freers elevator. Frontal process of maxilla , lacrimal crest and lacrimal bone exposed.. The junction between the lacrimal bone and lacrimal crest was identified.Lcrimal crest was punched using the Kerrysons bone punch. Lacrimal sac was widely exposed after widening the bony defect above the axilla of middle turbinate. Punctum dilator was used to dilate the superior and inferior puncta.Tenting effect caused by the lacrimal probe the lacrimal sac was confirmed endoscopically.Vertical incision was given on the medial wall of the sac. Perpendicular cuts were made over both ends of the vertical incision taking care not to injure the lateral wall of the sac. Medial wall of the sac was completely marsupialised. Lacrimal intubution set were passed through superior and inferior puncta to bring the attached silicon stent through the common cannaliculous which was tied in the nose.The mucoperiosteal flap was divided into two halves and placed over the inferior turbinate.A betadene soaked ANP was kept in the corresponding side of nose which was removed after 48 hours. Antibiotic eye drops were started. Follow up was done at 1 week post surgery and every 15 days for next three months, then monthly for six months and yearly thereafter. Stoma was checked endoscopically on follow up visits. Silicon stent were removed 6-7 weeks.

\section{Discussion:-}

Dacryocystitis is an inflammation of lacrimal sac leads to obstruction at the junction of lacrimal sac with the nasolacrimal duct. Females are more affected than males. The condition is rarely seen in males.Most patients are seen in third and fourth decade of life.Epiphora is commonest presentation seen in all the cases of nasolacrimal duct obstruction and chronic dacryocystitis. Mucoid or mucoprulent discharge from the medial canthal region are seen in 33 percent of cases. Some patients present with swelling in the lacrimal in the lacrimal sac region and regurgitation test positive in these cases. Dacryocystorhinostomy is surgical procedure in which nasolacrimal duct is bypassed by making an opening in the medial wall of lacrimal sac which drains directly in the nasal cavity.It can be performed by external route called external DCR. As Dacryocystitis is common in females so cosmesis is very impotant aspect to look.Nowadays endoscopic DCR is commonly performed in cases of nasolacrimal duct obstruction and chronic dacryocystitis. The study was done to comment on the rule of silicone stent in endoscopic DCR. 
Table 1:-Postoperative assessment in two groups

\begin{tabular}{|l|l|l|l|l|}
\hline $\begin{array}{l}\text { Postoperative assessment } \\
(10 \text { week) }\end{array}$ & $\begin{array}{l}\text { Group A } \\
(\mathrm{n}=18)\end{array}$ & percentage & $\begin{array}{l}\text { Group B } \\
(\mathrm{n}=18\end{array}$ & percentage \\
\hline Syringing patent & 17 & 94.44 & 16 & 88.88 \\
\hline Syringing blockade & 2 & 11.11 & 4 & 22.22 \\
\hline Nasal obstruction & $3 / 6$ & 2.77 & $2 / 5$ & 1.11 \\
\hline Synachea formation & 4 & 22.22 & 2 & 11.11 \\
\hline $\begin{array}{l}\text { Visualization of ostium in } \\
\text { lacrimal sac on DNE }\end{array}$ & 12 & 66.66 & 14 & 77.77 \\
\hline
\end{tabular}

Table 2:-preoperative clinical features in two groups

\begin{tabular}{|l|l|ll|lc|}
\hline Sl.no. & Presenting symptoms & Group A & \multicolumn{2}{|l|}{ Group B } \\
\hline 1 & Epiphora & $18 \quad 100 \%$ & \multicolumn{1}{l|}{18} & $100 \%$ \\
\hline 2 & Swelling in lacrimal region & 6 & $33 \%$ & 5 & $27.77 \%$ \\
\hline 3 & Mucoprulent discharge from medial canthus & 7 & $38 \%$ & 8 & $44.44 \%$ \\
\hline 4 & Congenital dacryocystitis & 3 & $16.6 \%$ & 2 & $11.11 \%$ \\
\hline 5 & Nasal obstruction(need septoplasty) & 5 & $27.77 \%$ & 6 & $33.33 \%$ \\
\hline
\end{tabular}

In our study epiphora was subsided in 17 out of 18 caeses in group A and 16 out of 18 in group B . Blockade was seen 2 and 4 cases in group A and Group B respectively. Mucoprulent discharge subsided in all the cases in both the groups. Synechea formation was seen in 4 cases in group A and 2 cases in group B.nasal ostium visualized in 14 cases in group A and 12 cases in Group B. One failure was seen in group A had mucosal adhesions to the sac on DNE while in group B , there were two failures one was due to incoml;ete opening of the sac and other was due to mucosal; adhesions to the sac wall.

\section{Conclusion:-}

Role of using silicon stent in endoscopic DCR is not very promising because it is not improving the outcome of surgery rather than it has been seen more granulation tissue in stent patient that may cause failure in latere part of life10 . meanwhile silicon stent adds the cost to surgery and it also causes irritation to the patient. Endoscopic DCR without stent is treatment of choice in patients of NLD blockage and chronic dacryocystitis.

\section{References:-}

1. Metson R, Woog JJ.Puliafitop CA. Endoscop[ic laser dacryocystorhinostomy. Laryngoscope 1994Mar;104(3 pt 1);269-274

McDonough M, Meiring JH. Endoscopic transnasal dacryocystorhinostomy. J laryngol otol 1989;103(6):585587

Leong SC. Macewen CJ. White PS. A systematic revew of outcomes after dacryocystorhinostomy in adults. M J Rhinol Allergy. 2010 Jan -Feb,24(1);81-90

2. Feng YF, Cai JQ, Zhang JY, Han XH. A meta-analysis of primary dacryocystorhinostomy with and without silicon intubation. Can J Opthalmol.2011 Dec;46(6):521-7

3. Syed MI ,Head EJ ,madurka M,HendryJ .endoscopic primary dacrocystorhinostomy;are silicon tubes needed ? our experience in 63 patients .clin otolaryngol.2013 oct ;38(5):406-10

4. Gu Z , Cao Z.silicon intubation and endoscopic dacrocystorhinostomy:a meta analysis .J Otolaryngol head neck surg .2010 Dec;39(6):710-3

5. Tsirbas A, Wormald P J ,endonasal dacrocystorhinostomy with mucosal flaps .Am J opthalmol.2003 jan;135(1) $: 76-83$

6. Saeed BM .endoscopic DCR without stents :clinical guidelines and procedure .Eur Arch otolaryngol relat Spec.2006 aug ;68(5):266-9

7. Allen K, Berlin AJ. Dacryocystorhinostomy failure: association with nasolacrimal silicon intubation. Opthalmol Surg $1989 \mathrm{Jul} ; 20(7): 486-489$

8. Jordan DR , Anderson RL. Prevention of prolapsed siliconestents in dacryocystorhinostomy surgery(Letter). Arch Opthalmol1987 Apr ;105(4):455. 